\title{
Similes in Parts Twenty-Ninth and Thirty of the Holy Quran
}

\author{
Nizar A. Al-Dmour ${ }^{1}$, Omar A. Al-Sa'oudi ${ }^{1}$ \\ ${ }^{1}$ Department of Arabic Language and Literature, Tafila Technical University, Jordan \\ Correspondence: Nizar A. Al-Dmour, Department of Arabic Language and Literature, Tafila Technical University, \\ Jordan.
}

Received: April 13, 2021

doi:10.5430/elr.v10n2p12

\author{
Accepted: May 12, $2021 \quad$ Online Published: May 19, 2021 \\ URL: https://doi.org/10.5430/elr.v10n2p12
}

\begin{abstract}
This study aims to analyze the Quranic similes in Parts Twenty-ninth and Thirty of the Holy Quran as they contain 48 Surah from a total of 114 Surah, with a percentage of $42 \%$. They are Makkan Surah except for four of them (Surah Al-Insan, Surah Al-Bayyina, Surah Al-Zalzala, Surah An-Nasr). The study consists of two topics; the first one addressed the theoretical aspects of the term, the importance of simile and its role in clarifying the intended meaning. The second topic addressed the applied aspects by collecting, studying, analyzing, and examining the close linguistic meanings of similes, up to demonstrating their beauty and comparing them with other similes in other places in Quran. For this purpose, the researchers used the two tools of textual approach; description and analysis as the approach used in this study.
\end{abstract}

Keywords: elements, meaning, quran, simile, structure

\section{Introduction:}

This research aims to study one of the most important eloquence elements, which is simile. Arabs have become aware of the powerfulness and precedency of simile, and it was commonly used in their poetry and prose. Simile is one of the instinctual characteristics of a human being, a basic process of thinking in terms of cognation and composition, and one of the first eloquence forms in history because it preceded metaphor and allusion in terms of time (Al-Esawi 1988, 23 - 25).

Therefore, simile was heavily used in the words of Almighty Allah, the words of his prophet (PBUH), and the eloquent speech of the ancient people and scholars alike. It is even found in non-eloquent speech as a result of multi-environments. Great similes can be found in the speech of regular people if they were put in the right formats to become impactful and important. Simile is not a means to reach another style, namely metaphor, as some of the writers' phrases might delude. Simile itself is a goal; if the aim of eloquence was making an impact on people, then its most important influential part is similes (Abbas 1987).

\section{Theoretical Aspects}

Arabic literature contains many works by authors who wrote in the art of simile, most of them are in Arabic poetry, including: "Rawayie Altawjihat Fi Badayie Altashbihat" by Abi Sa'ad Nasr Bin Yaqoub Al-Dainori, "Gharayib Altanbihat Ealaa Eajayib Altashbihat" by Ibn Dafer, "Altashbihat" by Abi Amer Al-Alawi, "Alrawdat Alsahiliat Fi Al'awsafWaltashbihat" by Ahmad Bin Mohammad Al-Khawarizmi, "Altashbihat Min 'Iishear 'Ahl Alaindils" by Ali Bin Mohammad Al-Andulsi, "Altashbihat" by Mohammad Bin Ishaq Al-Nadeem, and "Aljaman Fi Tashbihat Alquran" by Ibn Naqia Al-Baghdadi which was characterized by being the only book written in Quranic Simile.

However, Ibn Naqia addressed similes from two aspects; comprehension, and perception. He interpreted the Quranic meaning in the verse following it by a poem that has an identical meaning without much analysis. He also used the method of weighing these two meanings. He did not look into meanings of Quran since he considered it inimitable. He believed the nature of human minds and their ideas are incomparable to Quran, and authors are unable to write in the same language used (Al-Baghdadi 1985). He associated Quran with the concept of"Assrfah" (Diversion of Intent) which many scholars believed in. Other scholars, including Al-Sayooti, objected and disapproved this notion (Al-Shahhat 1988).

Language is derived from sensual and spiritual perceptions. The human mind knows only little of Allah's knowledge. A large part of this knowledge will remain unknown due to many factors. Therefore, Almighty Allah wanted to make this knowledge approachable to people by stating examples, telling stories, mentioning events, and using simile, 
representation, and metaphor. Al-Jarjani believed that these were the first eloquent styles; they are large sources from which beautiful words were derived, as if they were poles around which meanings revolve, or diameters surrounding them from every direction (Abu Hamda 1983).

\subsection{The Concept of Simile}

Linguistically, simile is representation. It is derivation of "make similar to". Ibn Manthoor said: resemblance, being similar to, and look alike mean: being identical with its plural form is "likes". When something is similar to another, it means they are identical, and the same applies when one says he resembles someone else or that he mistook something for something else (IbnMandoor 1999).

Scholars have mentioned many definitions for simile, including Al-Baqellani. He stated that "simile is when one believes that something fills the position of something else in reality or mind (Al-Baqellani, 1986). In addition, Al-Jarjani defined it by saying "simile proves the meaning or trait of two things under comparison" (Al-Jarjani 1976, p. 64).

Moreover, Al-Sakkaki, stated that "simile includes two parties: tenor and vehicle; they are similar in one aspect and different in another" (Al-Sakkaki 1983, p. 177), so they all serve the same meaning. However, he was more inclusive since he mentioned the two parties of simile along with the ground of similarity to indicate that they share the same apparent or hidden meaning.

Simile is a type of figures of speech which is "arranging meanings in one's heart, and organizing it in the mind" (Al-Jarjani 1976, p. 4). It is a progressive process that experience language in all its dimensions, and its new additions and strengthening of concepts while keeping up with the mental matters and comprehending the era's facts" (Abu Hamda 1983, p. 5).

\subsection{The Importance of Simile}

Al-Jarjani expressed the importance of simile and its impact on expressing different meanings in a beautiful manner by saying "representation gives meanings greatness and virtue, raises their level, makes them more passionate, and attract hearts to them" (Al-Jarjani 1976, p. 93). He believes that if a simile is a compliment, it would have greater impact on people. However, if it is a slander, its impact will be more severe, and so on in arguments, boasting, apologizing, or preaching.

Al-Sakkaki stayed close to those meanings when describing simile as a type of eloquence. He said: "it adds honor and clarification to the meaning, increases its powerfulness and affirmation, and elevates it so that minds and hearts are attracted to it. This is because simile directs the perceiver to a similar image of the original one. The farer the image was from the original, the more the simile was impactful, admirable, and had long-term influence in terms of expressing different meanings" (Al-Hashimi 1978, p. 286).

Moreover, Shawqi Daif (1994) affirmed that the original and basic function of simile is depiction and clarification through shifting from something to a similar thing. Simile becomes more beautiful when the image is odd and far from the original word.

Therefore, simile was the most vivid and expressive art to express the Arabic environment in its different eras and areas. There are many forms and types of simile in pre-Islamic poetry and the early years of Islam, as well as in Quran. These similes were used to depict the meaning in the best way possible, and make the form more splendid. Holy Quran's similes had an important impact on Arab's speech. Thus, poets used them in their poems and writers made them the foundation of their depiction" (Al-Sagheer, 2004, p.64).

Here, there is a reference to the impact of simile from two aspects: first, meaning and accuracy of depiction, which activates imagination of the reader, and takes him to another atmosphere that he cannot see at that moment - at least - but he is acquainted with it and has lived it before. The second aspect is form; simile in its different types elevates speech, offering rhythmical music to the sentence in the best way possible whether it was a single, compound, multiple, or implicit simile (Al-Sagheer 2004).

\section{Applied Aspects}

\subsection{Methodology}

The study area consists of forty-four Surahs with a percentage of 51\% of Makkan Surahs. Quranic similes in parts twenty-ninth and thirty were collected in the following table in order to facilitate referencing, discussing, and analysis. Note that the Surahs were arranged according to the date of revelation. The two tools of textual approach, description and analysis, are used in this paper. 
Table 1. Quranic similes in parts twenty-ninth and thirty

\begin{tabular}{|c|c|c|c|c|}
\hline & Verse & Number & Surah & Simile Type \\
\hline 1 & $\begin{array}{l}\text { "So there came upon the garden an affliction from your Lord } \\
\text { while they were asleep. And it became as though reaped". }\end{array}$ & $19-20$ & Surah Al-Qalam & Metonymic simile \\
\hline 2 & $\begin{array}{l}\text { "Such is the punishment [of this world]. And the punishment } \\
\text { of the Hereafter is greater, if they only knew". }\end{array}$ & 33 & Surah Al-Qalam & Metonymic simile \\
\hline 3 & Then will We treat the Muslims like the criminals? & 35 & Surah Al-Qalam & Reverse simile \\
\hline 4 & $\begin{array}{l}\text { Then be patient for the decision of your Lord, [O } \\
\text { Muhammad], and be not like the companion of the fish [i.e., } \\
\text { Jonah] when he called out while he was distressed. }\end{array}$ & 48 & Surah Al-Qalam & Metonymic simile \\
\hline 5 & $\begin{array}{l}\text { Indeed, We have sent to you a messenger as a witness upon } \\
\text { you just as We sent to Pharaoh a messenger. }\end{array}$ & 15 & Surah Al-Muzzammil & Detailed simile \\
\hline 6 & $\begin{array}{l}\text { One Day the earth and the mountains will be in violent } \\
\text { commotion. And the mountains will be as a heap of sand } \\
\text { poured out and flowing down. }\end{array}$ & 14 & Surah Al-Muzzammil & effective simile \\
\hline 7 & $\begin{array}{l}\text { Then what is the matter with them that they turn away from } \\
\text { admonition?- } \\
\text { As if they were affrighted asses, Fleeing from a lion! }\end{array}$ & $49-51$ & Surah Al-Muddathir & Multiple simile \\
\hline 8 & $\begin{array}{l}\text { Then did He make them like an empty field of stalks and } \\
\text { straw, (of which the corn) has been eaten up. }\end{array}$ & 5 & Surah Al-fil & Metonymic simile \\
\hline 9 & (It is) a Day whereon men will be like moths scattered about, & 4 & Surah Al-Qaria & Metonymic simile \\
\hline 10 & And the mountains will be like carded wool. & 5 & Surah Al-Qaria & Metonymic simile \\
\hline 11 & $\begin{array}{l}\text { Did We not destroy the men of old (for their evil)? } \\
\text { So shall We make later (generations) follow them. } \\
\text { Thus do We deal with men of sin }\end{array}$ & $16-18$ & Surah Al-Mursalat & Detailed simile \\
\hline 12 & For what Day are these (portents) deferred? & 32 & Surah Al-Mursalat & Metonymic simile \\
\hline 13 & $\begin{array}{l}\text { "As if there were (a string of) yellow camels (marching } \\
\text { swiftly)." }\end{array}$ & 33 & Surah Al-Mursalat & Detailed simile \\
\hline 14 & $\begin{array}{l}\text { "Eat ye and drink ye to your heart's content: for that ye } \\
\text { worked (Righteousness). } \\
\text { Thus do We certainly reward the Doers of Good. }\end{array}$ & $43-44$ & Surah Al-Mursalat & Metonymic simile \\
\hline 15 & $\begin{array}{l}\text { 'And they (came to) think as ye thought, that Allah would not } \\
\text { raise up any one (to Judgment). }\end{array}$ & 7 & Surah Al-Jinn & Metonymic simile \\
\hline 16 & $\begin{array}{l}\text { "'And made the moon a light in their midst, and made the sun } \\
\text { as a (Glorious) Lamp }\end{array}$ & 16 & Surah Nooh & effective simile \\
\hline 17 & $\begin{array}{l}\text { "'And Allah has made the earth for you as a carpet (spread } \\
\text { out), }\end{array}$ & 19 & Surah Nooh & effective simile \\
\hline 18 & $\begin{array}{l}\text { He made it rage against them seven nights and eight days in } \\
\text { succession: so that thou couldst see the (whole) people lying } \\
\text { prostrate in its (path), as they had been roots of hollow } \\
\text { palm-trees tumbled down! }\end{array}$ & 7 & Surah Al-Haaqqa & effective simile \\
\hline 19 & Truly man was created very impatient;- & 8 & Surah Al-Maarij & Metonymic simile \\
\hline 20 & And the mountains will be like wool, & 9 & Surah Al-Maarij & Metonymic simile \\
\hline 21 & $\begin{array}{l}\text { The Day whereon they will issue from their sepulchers in } \\
\text { sudden haste as if they were rushing to a goal-post (fixed for } \\
\text { them),- }\end{array}$ & 43 & Surah Al-Maarij & Detailed simile \\
\hline 22 & Have We not made the earth as a wide expanse, & 6 & Surah An-Naba & effective simile \\
\hline 23 & And the mountains as pegs? & 7 & Surah An-Naba & effective simile \\
\hline 24 & And made the night as a covering, & 10 & Surah An-Naba & effective simile \\
\hline 25 & And placed (therein) a Light of Splendor? & 13 & Surah An-Naba & effective simile \\
\hline 26 & And the heavens shall be metonymic as if there were doors, & 19 & Surah An-Naba & effective simile \\
\hline 27 & And the mountains shall vanish, as if they were a mirage. & 20 & Surah An-Naba & effective simile \\
\hline 28 & $\begin{array}{l}\text { The Day they see it, (It will be) as if they had tarried but a } \\
\text { single evening, or (at most till) the following morn! }\end{array}$ & 46 & Surah An-Naziat & Metonymic simile \\
\hline 29 & $\begin{array}{l}\text { Their thirst will be slaked with Pure Wine sealed: } \\
\text { The seal thereof will be Musk: And for this let those aspire, } \\
\text { who have aspirations: }\end{array}$ & $25-26$ & Surah Al-Mutaffifin & effective simile \\
\hline 30 & $\begin{array}{l}\text { And round about them will (serve) youths of perpetual } \\
\text { (freshness): If thou seest them, thou wouldst think them } \\
\text { scattered Pearls. }\end{array}$ & 19 & Surah Al-Insan & Metonymic simile \\
\hline
\end{tabular}




\subsection{Findings and Discussion}

Based on the similes used in these two parts, the Holy Quran focuses on two types of similes:

Table2. Frequency of using metonymic and effective simile

\begin{tabular}{l|l}
\hline Type of Simile & Frequency \\
\hline Metonymic simile & 14 \\
\hline Effective simile & 10 \\
\hline
\end{tabular}

First: both of these types do not have grounds of similarity. They are more eloquent than other types of single simile so they allow the reader's imagination to flow. Omission of the ground of similarity predicts identical traits or proportionality, as in the case of metonymic simile. Metonymy is closer to comprehension than detailing due to the closeness of the tenor and vehicle or because they the reader have seen them repeatedly. Thus, the detailed simile was less used than the other types in about 4 verses only, along with one reverse simile and one multiple simile.

Some of grounds of similarity may be clear and easily understood by both the public and specialists, while others might be implicit that needs contemplation and consideration and are understood by specialists only. However, the researcher believes the mentioned similes are vivid and easily comprehended by any one.

It is noted that the similarity between mountains on the Day of Judgment (tenor)and the vehicle (mirage, wool in general or carded wool, and heap of sand) all share one ground of similarity, which is scattering, lightness, fading away even if the images are various. This is emphasized by other verses in Holy Quran (broken down, crumbling, dust dispersing...); each provides new images which Arabs are familiar with in their environment to make the meaning more understood and emphasize on it by providing other images.

Arabs are familiar with solid mountains. They mentioned them in their idioms to express solidness and stability. Quran has compared mountains to pegs which anchors the ground to prevent it from moving. Arab knew pegs; it is a tool used to tug the tent with a rope after anchoring it to the ground. When they wish to leave, they would pull it fast to untie the tent, so it was fully relatable to them when they used to reside or leave.

Allah has made these mountains the most important element in stabilizing the ground; which are firm mountains that do not shake, and He also made them the first element in erasing life on earth. In the Day of Judgment, earth shall be crumbled to atoms, dust scattered abroad, or sand piles heaped above one another. It might also be like a mirage, which they run toward believing it is water, but they would find nothing. This illusion or nothingness is the state of mountains on the Day of Judgment (And the mountains shall vanish, as if they were a mirage). Then, mountains become as if they were light-carded wool scattered in the air. In verse 88 of Surah An-Naml, Quran describes the mountains' movement as the movement of the clouds, since Arabs used to pay attention to the passing of clouds as well as its movement and speed in order to know the time of rainfall (Thou seest the mountains and thinkest them firmly fixed: but they shall pass away as the clouds pass away: (such is) the artistry of Allah, who disposes of all things in perfect order: for he is well acquainted with all that ye do).

Quran has also compared waves to mountains, and ships sailing smoothly to mountains in order to undermine the misconceptions and superstitions in their mind about these natural creatures and their role in life. Nevertheless, the destiny of mountains on the Day of Judgment is stated in verses 105-107 of Surah Taha., which combines the meaning of all these multiple images (They ask thee concerning the Mountains: say, "My Lord will uproot them and scatter them as dust; "He will leave them as plains smooth and level; Nothing crooked or curved wilt thou see in their place.".

Second: The examination of the instruments used in similes yielded the following results:

Table 3. Instruments used in similes

\begin{tabular}{l|l}
\hline Instrument & Frequency \\
\hline Kaf/As & 14 \\
\hline Ka'en/Like & 5 \\
\hline If & 1 \\
\hline
\end{tabular}

Using "Ka'en/Like" is eloquent than "Kaf/As". Therefore, it is used when the likeness is stronger between the two parties. The reader would not doubt the likeness of the tenor and vehicle as in the verses: (So that thou couldst see the (whole) people lying prostrate in its (path), as they had been roots of hollow palm-trees tumbled down!). We cannot imagine the Thamud's bodies being ripped apart to dead pieces scattered in every direction without imagining 
a huge number of large palms taken off from the roots thrown all over the place. The same applies in other verses: (The Day whereon they will issue from their sepulchers in sudden haste as if they were rushing to a goal-post (fixed for them); (As if they were affrighted asses, fleeing from a lion!); (The Day they see it, (It will be) as if they had tarried but a single evening, or (at most till) the following morn!).

Mentioning the instrument among eloquent scholars is called metonymic simile, and these scholars interpreted the meaning by saying "it is said spontaneously and uttered freely" (Abu Haqqa 1993, p. 125), which applies to human speech. Meanwhile in the Holy Quran, it indicates that almighty creator started addressing people by using words close to their minds, with the closer meanings to them, and linguistic instruments, styles, and forms known among them. However, it is very inimitable.

Third: The instrument in metonymic similes is mentioned, but it is omitted in effective similes. This made effective simile the most eloquent type of single - to - single similes, which is also the most famous and known simile among Arabs. However, Quran has chosen the most eloquent type, which is effective simile, whose instrument and ground of similarity was omitted, "because omitting the instrument indicates the sameness of the two parts, while omitting the ground of similarity indicates traits' inclusion. Therefore, (Effective simile) includes these two powerful characteristics" (Hussein 1992, p. 81).

We will address one of these similes, which is Verse (24) in the previous table. The night was compared to covering; a covering in origin is the known clothes worn by the human to cover. It was mentioned 10 times in 8 verses, and Allah has mentioned it expressly in Quran to remind all humans of His many blessings as in Surah Al-Aaaf which is the precedent in terms of revealing: ( $\mathrm{O}$ ye Children of Adam! We have bestowed raiment upon you to cover your shame, as well as to be an adornment to you. But the raiment of righteousness,- that is the best. Such are among the Signs of Allah, that they may receive admonition!). Then He reminded them of this blessing in Surah Al-Furqan which came in fourth after Surah Al-Araf: (And He it is Who makes the Night as a Robe for you, and Sleep as Repose, and makes the Day (as it were) a Resurrection) and He later referred to the paradise dwellers and that their clothes are made of silk in Surah Fatir.

In this verse, the night was compared to a covering (And made the night as a covering, And made the day as a means of subsistence?); when the night would cover people with darkness, it becomes covering and concealment for them. The blessing here lies in the fact that the darkness of the night hides a person from the eyes of others if he wanted to run from an enemy or to cover what he hates for others to know about him. Moreover, in the same manner a person would become more beautiful, powerful, and protected from heat and cold because of clothes, the night also increases the beauty and comfort of a person due to the benefits of sleeping, as well as keeping him away from physical tiredness and spiritual harmful thoughts and preserving his sensual, motor, and mental powers. When a sick person falls asleep at night, he finds great comfort.

The night is concealment, peace, comfort, and assurance. In addition, it is the time for quietness, peacefulness, and break from work. The day is the opposite of night, which is the time for work and search for decent living. It appears that the meaning behind this simile includes more than the meanings which interpreters have indicated.

Night includes two images; black and white. The first image is represented in the understanding of those who are going astray who think that night covers their crimes and sins in their meetings during the night believing that people would not see them so they are safe. They forgot that nothing is hidden from Allah, and that the night is a great blessing from Him, but they use it in doing acts that cause Allah's wrath. Moreover, it is not possible that the night which is one of Allah's creatures-, would become a barrier for them without Him knowing, hearing, and seeing them using the blessing in the opposite way of what it was created for.

As for the second image, the believer would allocate part of his good deed to do them during the night such as putting charity at the door of a poor person without being seen or known, praying, reading Quran while being afraid of pretension, seeker of forgiveness who is aware of the late night, so he prays and ask for forgiveness.

The acts of mercy, compassion, and kindness also appear during the night. For example, when the father or mother check on their children and put a blanket on them, or when he/ she stays up the night when they are sick. In the same manner, soldiers, doctors, and nurses stay up all night to protect, take care, and help people when they are in need at night.

Al-Fajr prayer is also prayed at the time of darkness; whenever a prayer walks to the mosque to perform Al-Fajr prayer, Allah would alleviate his fears, increase faith in his heart, hearing, and vision, and lighten up his surroundings. The contrast and opposition between light with the darkness of night is an intended part of this wonderful simile.

If this visual image among some people was dark and frightening to them, it is considered a bright, pleasing image to 
the believer, especially when he performs night prayers; Al-Maghrib, Al-Isha, and Al-Fajr prayers, and when he sleeps early to refrain from harming people or causing any disturbance to his neighbors.

In order for the image to be complete, Quran revealed in Al-Madina has contributed in creating a new image of covering when he compared women to garments; they are garments to their husbands and vice versa. It is one of the most wonderful similes by women and men being concealment to each other: (Permitted to you, on the night of the fasts, is the approach to your wives. They are your garments and ye are their garments). Although this section is not within the study limits, but the researchers will mention it since the comparison is wonderful.

The meaning of this simile includes all meanings mentioned by scholars, including closeness, connection, concealment, beautification, covering, pleasure, assurance, and protection. Just as much as you need clothes to protect you from coldness and hotness, spouses need each other in hardest circumstances. The human feelings become higher than the animal level when he satisfies his body needs and when spouses keep each other away from deviation and desires, concealing each other's flaws. The marital relationship is a complementary one. Each completes the other, makes up for his flaws, and corrects his mistakes. Therefore, choosing a suitable wife is important. Furthermore, just as patience is needed with tight clothes, spouses need to be patient with each other's mistakes. Also, behaviors of the husband and wife need to be changed and renewed from time to time just as clothes is in need to be changed. Lastly, the marital relationship should reach great harmony as if they were one body in one-piece clothes. Eloquent Arabs understood these meanings. Therefore, they highly appreciated women and put her in her proper position as part of their understanding of Quran's similes and instructions. This also made Arabs understand Quran's message about night. Thus, scholars, worshipers, advocates, good-doers, forgiveness-seekers, and mujahidin have all appreciated it.

Fourth: Both parties of the simile are realized with the five senses. "When Quran compares something that can be sensed to another, it aims to draw an image felt by the heart" (Sharshar 1983, p. 135).

Quran has compared the sky to molten brass and doors, mountains to wool, pegs, mirage, and carded wool, earth to couch, night to garment, the scent of nectar (wine) to musk, men to scattered moths, and the companions of the elephant to scattered stalks and straw that was eaten by animals then these animals spitted and stepped upon it. This image was used as an offense to those disbelievers.

Most of these similes are of single, non-compound type in order to make it easier to understand by the listener without much explanation, especially that the vehicle exists in the listener's environment. The listener has felt and is familiar with it, which makes the notion and image clear to him/her. "Thus, in the Holy Quran, the examples of Arabs show them yearning for water, shades, trees, or enjoying rivers, shades, green paradises, and other things that are part of their lives in which they have lived, worked, became familiar with, or hated" (Al-Atraqchi 1978, p.8).

These similes were derived from the nature. For example, plants (hollow palm-trees, scattered stalks and straw, (of which the corn) has been eaten up), animals (camels, zebras, lions, moths), and non-living things (pegs, clothes, doors, wool, pearls, castles). "All these elements are not limited to a specific, time, place, or nation. On the other hand, they are indispensable things in humans' lives, which increase its influence on the heart" (Abbas 1987, p. 87). These things are also visible to the eyes, touched by hand, tasted by the tongue, smelled by the nose, or heard by the ears as in this terrifying image of flying sparks in this verse ("Indeed it throws about sparks (huge) as Forts). In this image, the man is looking at this huge sparks, distinguishing its dark colors, smelling the rising smoke like piled mountains, hearing the shelling of fire in within. Therefore, this person tries to close his ears to silence this loud sound. However, its faint sound is heard from far away, so he trembles in fear, fearing to be hit by the sparks flying above his head, which are as big as a huge castle or fort. Then, his tongue becomes dry fearing to get into the fire and feeling its heat.

In order for the image to be complete, the researcher will compare the last simile to other similar similes in the Holy Quran according to the time of revelation through the following table: 
Table 4. Comparisons to other similar similes

\begin{tabular}{|c|c|c|c|}
\hline The Tenor & The Vehicle & $\begin{array}{c}\text { The Meaning of The } \\
\text { Vehicle }\end{array}$ & The Verse \\
\hline \multirow{4}{*}{$\begin{array}{l}\text { The tenor here is the } \\
\text { disbelievers who caused } \\
\text { Allah's wrath. Allah } \\
\text { punished them despite } \\
\text { their power and might. } \\
\text { The same applies on } \\
\text { whoever follows their } \\
\text { path until the Day of } \\
\text { Judgment }\end{array}$} & $\begin{array}{l}\text { scattered stalks and straw, } \\
\text { (of which the corn) has } \\
\text { been eaten up }\end{array}$ & $\begin{array}{l}\text { The leaves in its worst } \\
\text { state; when the leaves are } \\
\text { chewed, fallen on the } \\
\text { ground and then stepped } \\
\text { upon until they become } \\
\text { dry stew flying because } \\
\text { of the wind. }\end{array}$ & $\begin{array}{l}\text { (Then did He make them like an empty } \\
\text { field of stalks and straw, (of which the } \\
\text { corn) has been eaten up). } \\
\text { Surah Al-fil (5) }\end{array}$ \\
\hline & dry stubble & $\begin{array}{l}\text { Dry plants that are } \\
\text { smashed and stepped } \\
\text { upon by animals }\end{array}$ & $\begin{array}{l}\text { (For We sent against them a single Mighty } \\
\text { Blast, and they became like the dry } \\
\text { stubble used by one who pens cattle). } \\
\text { Surah Al-Qamar (31) }\end{array}$ \\
\hline & Ruin & Dry smashed leaves & $\begin{array}{l}\text { (And in the 'Ad (people) (was another } \\
\text { Sign): Behold, We sent against them the } \\
\text { devastating Wind: It left nothing whatever } \\
\text { that it came up against, but reduced it to } \\
\text { ruin and rottenness). } \\
\text { Surah Adh-Dhariyat (41-42) }\end{array}$ \\
\hline & rubbish of dead leaves & $\begin{array}{l}\text { (floating on the stream of } \\
\text { Time) what floats on the } \\
\text { stream whether leaves, } \\
\text { sticks, dirt, and rubbish. } \\
\text { The stream flows with } \\
\text { them while they are } \\
\text { scattered and incoherent. }\end{array}$ & $\begin{array}{l}\text { (Then the Blast overtook them with } \\
\text { justice, and We made them as rubbish of } \\
\text { dead leaves (floating on the stream of } \\
\text { Time)! So away with the people who do } \\
\text { wrong!)Surah Al-Mumenoon (41) }\end{array}$ \\
\hline
\end{tabular}

Here, the ground of the similarity between these things and those whom a judgment was made upon them such as the Companions of the Elephant, the people of Aad and Thamoud and other disobeyers and tyrants, is the ill fate and worthless destiny. First, verses started comparing them to chewed leaves stepped upon by feet, or smashed crushed leaves flying everywhere. Then at the end, Quran compared them to dry dead leaves (floating on the stream) carried by water with no value, weight, or benefit. These images are known to Arabs; they have seen them and are familiar with them. This image has brought the terrible eventual destiny of those wrongdoers and disobeyers closer to the minds.

It is worth pointing out the accuracy of Quranic terms, which is an important element in the inimitable Quranic eloquence. Quran did not only describe them as field of stalks and straws, but Quran added the term chewed or eaten. When an animal chews grass, part of it falls on the ground, so the animal would step on it. This is the purpose of the image in order to emphasize insult and contempt.

Quran has also described wind as barren as a metaphor of barren women who cannot conceive a child. This wind does not fertilize trees, but it was sent for torture and doom. Therefore, the terrifying image expressed the terrifying outcome when the wind left the disobeyers decayed.

Accordingly, the preciseness and beautiful expressions can be seen in the following verse "If thou seest them, thou wouldst think them scattered Pearls". The pearl is beautiful and attractive to the eyes, but in the image it was scattered and distributed beautifully and in harmony. This image is very wonderful and graceful since these youth are coming out in an organized, active manner serving the dwellers of Paradise all around. Their beauty is seen by all eyes, and all minds are bewildered by their numbers. In addition, moths were described as scattered to indicate how it is scattered incoherently so the image of fear and panic intensifies as in the verse "(It is) a Day whereon men will be like moths scattered about". As a result, the simile's objectives are achieved since it is a main element and part of the sentence. It is not an addition, literary excess, or a decoration to the text.

\section{Conclusion:}

The study attempted to examine the Quranic verses in Parts Twenty-Nine and Thirty by looking into simile meanings in various contexts as well as the relationship between the tenor and vehicle. Moreover, the study examined the places where the ground of similarity was mentioned or omitted, the role of instruments, the simile eloquence and inimitability. The study concluded the following results:

1. The Holy Quran focused on two types of similes; metonymic simile, and effective simile which were the most repetitive ones in these parts. These similes are single -to single non-compound simile and are the most eloquent and rhetoric types because they both have omitted grounds of similarity. 
2. Both parts of the similes are sensuous so that they are easy and do not need too much imagination or long time to understand, especially that the vehicle exists in the listener's environment. The listener has felt and is familiar with it, which makes the notion and image clear to him/her.

3. The most repetitive instrument was 'As', which always follows the vehicle. Allah's speech is dedicated to humans in order to guide them to the truth, choosing words that are suitable to their reality, and using various figures of speech.

4. The similes achieved their objectives, which were shown through comparisons with other verses in the Quran. There was no disparity among similes, since one of Quran's characteristics is stability and realism.

5. The similes of Quran are derived from the rest of the elements of the surrounding nature, which people are familiar with.

\section{References}

Abbas, F. H. (1987). Eloquence Arts and Kinds (Figures of Speech and Innovation). Dar Al-Furqan Publication, Amman.

Abu Hamda, M. A. (1983). Figures of Speech Styles in Holy Quran. Al-Resala Library, Amman.

Abu Haqqa, A. (1993). Eloquence and Literary Analysis. Dar Al-Elem Lil Malayyen Publication, Beirut.

Al-Atraqchi, W. M. (1978). Quranic Similes and Arabic Environment. Studies Series, (143).

Al-Baghdadi, I. N. (1985). Aljaman Fi Tashbihat Alquran (M. S. Al-Jweini, Edit.). Al-Mara'ref Establishment, Alexandria.

Al-Baqellani, A. M. (1986). The Inimitability of Quran (E. A. Haidar, Edit.). Al-Kutub Al-Thaqafiya Institution, Beirut.

Al-Esawi, A. (1988). Similes Eloquence (Artistic Historical Study). Cairo Al-Jadida Press.

Al-Hashimi, A. (1978). The Jewelry of Eloquence. Dar Al-Fiker Publication, Beirut.

Al-Jarjani, A. (1976). The Secrets of Eloquence, explanation and comments (M. A. Khaffaji, Edit.). Cairo Library.

Al-Sagheer, M. H. (2004). The Fundamentals of Arabic Figures of Speech. Dar Alshoon Althaqafiya Publication, Baghdad, Iraq.

Al-Sakkaki, Y. (1983). The Key to Sciences (N. Zarzour, Edit.). Dar Al-Kutub Al-Elmia Publication, Beirut.

Al-Shahhat, M. A. (1988). The Rhetoric Research in the Holy Quran. Al-Amana Publication, Egypt.

Daif, S. (1994). Literary Criticism. Dar Al-Maaref, Cairo.

Hussein, A. (1992). Quran and Figures of Speech. Dar Al-Manar Publication, Cairo.

IbnMandoor, J. D. (1999). The Arab Tongue. Dar Sader Publication, Beirut.

Sharshar, M. H. (1983). Qabas from Quranic Figures of Speech. Dar Al-Tiba'a Al-Muhammadiya Publication, Cairo. Sheikh A. B. (1994). The Artistic Expression in Holy Quran. Dar Al-Elem Lil Malayyen Publication.

\section{Copyrights}

Copyright for this article is retained by the author(s), with first publication rights granted to the journal.

This is an open-access article distributed under the terms and conditions of the Creative Commons Attribution license (http://creativecommons.org/licenses/by/4.0/). 